\title{
Integration Alternatives for Ship Designers and Shipyards
}

\author{
Dag E. Gotteberg Haartveit ${ }^{1}$, Marco Semini ${ }^{1}$, and Erlend Alfnes ${ }^{2}$ \\ ${ }^{1}$ SINTEF Technology and Society, Department of Industrial Management \\ Trondheim, Norway \\ ${ }^{2}$ Department of Production and Quality Engineering, \\ Norwegian University of Science and Technology, Trondheim, Norway \\ \{dag.haartveit, marco.semini\} @sintef.no, \\ erlend.alfnes@ntnu.no
}

\begin{abstract}
The offshore oil industry in Norway has for decades required advanced special purpose equipment for its operations. Norwegian shipbuilders have supplied the offshore industry and specialized in producing customized and technologically advanced ships. Shipbuilding is a typical Engineer-to-Order (ETO) industry. While the ship concept and design continues to be developed in Norway, ship production is increasingly performed at foreign yards. This characteristic makes the industry an interesting case for studying integration between actors. This paper presents a typology of different integration alternatives for ship designers and shipyards. The three alternatives presented are ownership, partner yard and market yard. The paper also identifies and discusses industry-relevant business factors that are affected by the choice of integration level.
\end{abstract}

Keywords: Supply Chain Management, Vertical Integration, Engineer-toOrder, Shipbuilding.

\section{Introduction}

Despite the fact that Engineer-to-order (ETO) manufacturing is widespread in many industries, and customization has been promoted as a source of competitive advantage [1], operations and supply chain management have mainly focused on high-volume manufacturing. In contrast to high-volume manufacturing, ETO manufacturing is characterized by low-volumes, high degrees of customization and project-based processes. Research addressing the design and management of supply chains with those characteristics is scarce [2]. This paper addresses collaboration and integration between supply chain actors in the archetypical ETO industry: shipbuilding. The shipbuilding industry is by definition concerned with the production of vessels above 100 gross tones. The industry is characterized by site production, temporary work organization, high degrees of customization and project organizations. The shipbuilding process is usually an endeavor lasting several years. During the process customer specifications, technological advances and other factors change the design 
of the ship. These changes demand collaboration between, and integration of, actors in order to be successful. Different levels and types of integration affect crucial business factors which imply different advantages and drawbacks. Choosing the right integration alternative should therefore be made in a systematic, informed way. There is however a lack of research addressing this issue.

The purpose of this paper is to develop a typology of different integration alternatives between two key actors in shipbuilding, the ship designer and the shipyard, and to identify the effects of different integration choices. The outcome should support managers in their effort to align supply chain strategy with overall business strategy and priorities.

The stated purpose is achieved by performing a literature review and several exploratory case studies at a Norwegian shipbuilder. The specific advantage of case studies is that great insight can be achieved by means of direct contact with key informants.

The case company produces customized and technologically advanced ships. The ships are tailor made to customer needs and especially attractive to customers providing services for the offshore oil industry. While the ship concept and design still are developed by the case company in Norway, ship production is increasingly performed globally; in countries and regions such as China, Brazil and the Middle East. This characteristic makes the case company an interesting case for studying integration between ship designer and shipyards. The topic of this paper is relevant to the case company and the study was conducted through frequent interviews and discussions with key personnel.

The remainder of this paper is structured as follows: First, the shipbuilding industry is briefly introduced. This introduction focuses on aspects relevant for the purpose of the present paper. Next, existing literature on vertical integration and supplier relations is reviewed. Chapter four contains this paper's main contribution; three different integration alternatives between designers and yards are introduced and their effect on industry-relevant factors highlighted. The paper is finalized by a conclusion and suggestions for further research.

\section{$2 \quad$ Shipbuilding}

This chapter will introduce shipbuilding characteristics relevant to the topic at hand. The characteristics are based on the case study. Ships for other market segments are often built differently.

\subsection{Main Processes}

Ships are complex engineered systems, and building ships is similar to building heavy machinery, capital goods or buildings. Such undertakings are usually organized as projects, and shipbuilding can therefore be considered as a project-based industry. A typical shipbuilding project includes the following main processes: 
- Concept design

- Contract design

- Basic and functional design
- Purchasing

- Engineering

- Production
- Assembly

- Commissioning

- After-sale

The different processes often overlap and their borders are blurred. Even the order and amount of effort put into each process can vary. Note that contract signing happens after Concept -, Contract -, and Basic and functional design. These non-physical processes are considered core capabilities for ETO companies [3].

\subsection{Main Actors}

The processes presented in the previous section are often not carried out by a single company, but a network of geographically dispersed actors. The processes carried out by each actor vary and so does the level of integration and coordination between them. This is an important characteristic of shipbuilding. At an aggregated level our case study revealed the following main roles, which may or may not belong to the same company:

- $\quad$ The ship designer

- The shipyard
- Main equipment suppliers

- The ship owner

There is a need for actors holding these roles to communicate and collaborate. This paper focuses on the ship designer and the shipyard which are presented in more detail below. Collaboration between them is needed to ensure effective, high quality production according to specifications.

The Ship Designer. The ship designer has the overall responsibility of concept design and basic and functional design. These two processes are the ones that determine the physical shape, performance and capabilities of the ship. These are ultimately the most important factors to the customer, thus the ship designer usually also carries out the marketing and communication efforts towards customers.

The Shipyard. The shipyard's main responsibility is production and assembly. In addition, it carries out purchasing and engineering, which are typically split between the ship designer and the yard to varying degrees. The shipyard is either chosen by the customer or in collaboration with the ship designer.

\section{$3 \quad$ Literature Review}

The literature review conducted for the paper covers design and management of supply chains with a focus on vertical integration and supplier relations, as this is relevant theory when discussing different levels of integration between companies. Special attention is given to literature concerning ETO companies and supply chains. Research in this field is not nearly as comprehensive as that of the high volume industry, but there is some relevant literature addressing the engineering and construction industry $[4,5]$. 


\subsection{Vertical Integration Decisions}

Vertical integration decisions are of strategic importance. These decisions determine how much of the supply chain the company will own and which activities it will perform. Companies usually vertically integrate to achieve one of two goals: To increase profit margins or to improve control over their business environment [6].

The result of vertical integration decisions affects companies on many levels. Porter [7] and Hayes and Wheelwright [6] explained the advantages and disadvantages of vertical integration. More recently, Beckman and Rosenfield [8] gathered the current body of knowledge and found four main sets of factors to be considered when making vertical integration decisions. The factors and their effects are summarized in Table 1.

Table 1. Factors For and Against Vertical Integration [8]

\begin{tabular}{lll}
\hline Factors & Vertically Integrate to: & Vertically Disintegrate to: \\
\hline Strategic & - Develop and retain core and & - Access a core or essential \\
Factors & essential competences. & capability externally while \\
& & working on its development \\
& & internally. \\
Market & - Control cost, quality, availability, & - Leverage competition among \\
Factors & features/innovativeness and & suppliers to access best-in-class \\
& environmental performance in & performance. \\
& unreliable markets. & - Aggregate demand at suppliers \\
& - Shift power relationships in the & thus generating economies of \\
& industry. & scale and improved \\
& - Reduce dependency on suppliers. & responsiveness to variability in \\
& & demand. \\
Product and & - Control integral or critical & - Access current technologies not \\
Technology & technologies. & available internally. \\
Factors & - Integrate design and production or & - Obtain leverage available from \\
& service delivery under certain & modular product architectures. \\
& conditions. & \\
Economic & - Minimize transportation and & - Access lower production or \\
Factors & logistics costs. & service delivery cost. \\
& - Minimize transaction costs. & - Minimize investment costs. \\
\hline
\end{tabular}

Hicks et al. [3] found that levels of vertical integration varied considerably between ETO companies and that these variations were consequences of the varying factors they were subjected to. At the same time they saw a trend towards vertical disintegration driven by financial pressure and cost reduction efforts.

\subsection{Enterprise Collaborations}

A company not completely vertically integrated must necessarily interact with other actors in a supply chain. This interaction varies depending on the relationship between 
the actors. According to Jagdev and Thoben [9] the collaboration between actors ranges from Market transactions to Integrated company. Table 2 illustrates the spectrum of relationships between two supply chain actors in which one acts as the supplier to the other. The level of formalization, commitment and duration of relationship increases downwards in the table.

Table 2. Spectrum of Relationships with Supply Chain Actors (Adapted from Jagdev and Thoben [9])

\begin{tabular}{ll}
\hline Type of Collaboration & Description \\
\hline Market Transaction & Relationship strictly transaction based. \\
Non-Contractual Agreements & Long lasting market transactions based on trust. \\
Contractual Agreements & Long-term supply contracts or agreements between \\
& companies providing complementary products. \\
License Agreements & License provided to supplier in technology that host \\
& firm develops. Example: franchising. \\
Joint Venture & Companies supplying complimentary products or \\
& services join forces for mutual benefit. \\
Integrated Company & A single company owns the activity. \\
\hline
\end{tabular}

Deciding what kind of relationship the company should have to other actors is a decision of strategic importance and should differ according to the role of the actor $[10,11]$. That role depends upon a number of factors including supply risk and impact on profit. These were identified by Kraljic [12] as the main determinants for a suitable sourcing strategy.

When considering supplier relations Hicks et al. [3] found that an ETO company could have the whole spectrum of relationships to its suppliers due to differing integration levels, the supply risk and impact on profit of the sourced product, and levels of desired concurrent engineering, to name a few. They also caution about the lack of transferability of supply chain management practices from the high volume sector. In the next chapter, the reviewed theory will be applied to shipbuilding with this warning in mind.

\section{$4 \quad$ Integration Alternatives}

Different forms and levels of integration exist between actors in shipbuilding. Despite the importance of selecting appropriate integration alternatives between different actors, the literature lacks frameworks addressing this issue. The purpose of this chapter is to develop a typology of integration alternatives for the ship designer and the shipyard, and to discuss consequences of different integration choices. The results are presented in table 3 . 
Table 3. Industry-Relevant Business Factors and How Integration Alternatives Affect Them

\begin{tabular}{|c|c|c|c|}
\hline & Ownership & Partner Yard & Market Yard \\
\hline $\begin{array}{l}\text { Strategic Factors } \\
\text { Capacity. Access to the right production } \\
\text { capabilities and capacity is essential and can } \\
\text { be scarce in high demand market situations. }\end{array}$ & $\begin{array}{l}\text { Full access to } \\
\text { capacity. }\end{array}$ & $\begin{array}{l}\text { Access to capacity } \\
\text { depends on } \\
\text { contractual } \\
\text { agreements. }\end{array}$ & $\begin{array}{l}\text { Access to capacity } \\
\text { depends on yard } \\
\text { availability and can } \\
\text { lead to lost sales. }\end{array}$ \\
\hline $\begin{array}{l}\text { Core Capability - Project Execution. Ships } \\
\text { are customized and adapted to customer } \\
\text { requirements throughout the project period. } \\
\text { Being able to comply with changes customers } \\
\text { require in an efficient manner is considered a } \\
\text { capability for shipbuilders, like the case } \\
\text { company. }\end{array}$ & $\begin{array}{l}\text { Integration } \\
\text { between functions } \\
\text { creates flexibility } \\
\text { through } \\
\text { collaboration and } \\
\text { coordination. }\end{array}$ & $\begin{array}{l}\text { Long-term } \\
\text { relationships } \\
\text { facilitate } \\
\text { collaboration and } \\
\text { coordination. }\end{array}$ & $\begin{array}{l}\text { Project changes } \\
\text { require } \\
\text { collaboration } \\
\text { between functions } \\
\text { with no experience } \\
\text { collaborating and } \\
\text { coordinating. }\end{array}$ \\
\hline $\begin{array}{l}\text { Core Capability - Knowledge. Designs are } \\
\text { to a large degree sold by referring to } \\
\text { previously built ships and the designers' }\end{array}$ & $\begin{array}{l}\text { Integration } \\
\text { between functions } \\
\text { secures knowledge }\end{array}$ & $\begin{array}{l}\text { Long-term } \\
\text { collaboration } \\
\text { facilitates }\end{array}$ & $\begin{array}{l}\text { Knowledge sharing } \\
\text { on a project-to- } \\
\text { project basis. }\end{array}$ \\
\hline
\end{tabular}
ability to develop solutions which exactly fits sharing. customer needs. Designing technologically advanced ships requires being able to integrate complex sub-systems and state-ofthe-art technologies. This requires knowledge and experience acquired by building ships.

\section{Market Factors}

Market Access. Ship production contracts are won on cost and political considerations. The yard industry is highly competitive and governments have been setting up tax schemes and local content regulations to promote production in their country. In order to benefit from those incentives customers will in many cases require a specific location/ yard. (Quality and perceived risk also influence choice of yard)

\section{Product and Technology Factors}

Intellectual Property. A shipyard with full access to detailed design drawings and the experience gained by building an offshore vessel is a potential competitor.

\section{Economic Factors}

Investment Costs. Shipyards are capital intensive and the market they compete in is volatile. This implies that the integration level has different capital investment requirements and risks associated with it.

Transaction Costs. Shipbuilding characteristics drives costs and integration between functions is identified to facilitate cost control [4].

\section{Production}

constrained to one or a small number of yards reduce market access.

\section{Full control of} integral or critical technologies. Low risk of intellectual property theft.

High investment requirements: Facilities, equipment, ITsystems and organizational changes.

Coordination costs and contract negotiations should be low or not existing.
Reduced risk of intellectual property theft due to long-term partnership.

Production, limited Production can be to a number of yards reduces market access. at any yard and does not reduce market access.
A market yard lacks long-term commitment and can easily become a competitor.

Low investment No investment requirements: IT- requirements. systems and organizational changes.
High transaction costs due to contract negotiations and complex coordination 
By taking the perspective of the ship designer, the integration alternative with the yard can be classified as ownership, partner yard, or market yard. This division is inspired by the work performed in the MODNET-project [13]. A similar division was mentioned but not further elaborated.

Ownership. Ownership implies that the designer and shipyard are part of the same company. The functions are thereby vertically integrated. This integration alternative also includes functions that are integrated through joint ventures. Ownership usually implies the highest level of collaboration.

Partner Yard. The partner yard alternative implies that long-term, contractual agreements or strategic alliances between the ship designer and the shipyard are in place. The ownership and partner yard alternatives imply that the ship designer will collaborate with specific yards several times. This creates incentives for improving collaboration.

Market Yard. The market yard alternative implies no long-term relationship. Contrary to the two other alternatives, this category implies a one-project-at-the-time focus for the collaboration between the actors. A ship designer will in practice have a limited number of vertically integrated yards or partner yards. For market yards, there are basically no restrictions.

Each pair of designer and yard can be characterized by its integration alternative. In practice, different shipbuilders adapt different strategies. Some build ships mainly through the ownership model, others pursue a more diversified strategy. The case company has for example evolved from being a shipbuilder in the ownership category to being in all three categories.

The three integration alternatives can be further characterized by how they affect various industry-relevant business factors. Such factors were identified in collaboration with the case company. They were structured into strategic, market, product and technology, and economic factors, as Beckman and Rosenfield [8] do in the context of vertical integration decisions (Table 1). Even though the division between partner yard and market yard is not a matter of vertical integration, the factors have been found relevant for comparing all the three integration alternatives.

\section{$5 \quad$ Conclusion and Further Research}

In this paper we have identified three different levels of integration between ship designers and shipyards. Industry-relevant business factors are identified and combined with the three integration alternatives in table 3. The table exemplifies consequences of the three integration choices. The theoretical contribution of this paper is thus a typology of different integration alternatives for ship designers and shipyards and the industry-relevant factors identified. The paper will hopefully contribute to managers' ability to take structured and informed decisions. The results 
should support efforts to align supply chain strategy with overall business strategy and priorities by presenting implications of each integration alternative.

The results presented in this paper rest mainly on case studies of several ship projects undertaken by a shipbuilder producing ships for the offshore industry. The proposed typology and industry-relevant factors should be validated by means of additional case studies from other shipbuilders, as well as surveys covering a larger number of shipbuilders. After validation the results could be generalized for all ETO industries. An additional opportunity for further research is to create a framework for deciding on integration levels between ship designers and main equipment suppliers.

\section{References}

1. Amaro, G., Kingsman, L.: Competitive advantage, customization and a new taxonomy for non-make-to-stock companies. International Journal of Operations \& Production Management 19(4), 349-371 (1999)

2. Gosling, J., Naim, M.M.: Engineer-to-order supply chain management: A literature review and research agenda. International Journal of Production Economics 122, 741-754 (2009)

3. Hicks, C., McGovern, T., Earl, C.: Supply chain management: A strategic issue in engineer to order manufacturing. International Journal of Production Economics 65(2), 179-190 (2000)

4. Venkataraman, R.: Project Supply Chain Management: Optimizing Value. The Way We Manage the Total Supply Chain (2007)

5. Yeo, K., Ning, J.: Integrating supply chain and critical chain concepts in engineer-procureconstruct (EPC) projects. International Journal of Project Management 20(4), 253-262 (2002)

6. Hayes, R.H., Wheelwright, S.C.: Restoring our competitive edge. John Wiley \& Sons, New York (1984)

7. Porter, M.E.: Competitive Strategy: Techniques for Analyzing Industries and Competitors. Free Press, New York (1980)

8. Beckman, S.L., Rosenfield, D.B.: Operations Strategy, Competing in the 21st Century, International ed. McGraw-Hill, New York (2008)

9. Jagdev, H.S., Thoben, K.D.: Anatomy of enterprise collaborations. Production Planning \& Control 12(5), 437-451 (2001)

10. Persson, G., Håkansson, H.: Supplier segmentation-when supplier relationships matter. IMP Journal 1(3), 26-41 (2007)

11. Bensaou, M.: Portfolios of buyer-supplier relationships. Sloan Management Review 40(4), 35-44 (1999)

12. Kraljic, P.: Purchasing must become supply management. Harvard Business Review 61(5), 109-117 (1983)

13. Longva, T., Horgen, R., Brett, P.O.: Teknisk rapport, DP1 - Konkurransekraftutvikling, verdiskaping og usikkerhet ved samvirkende forretningskonsepter i norskkontrollert skibsbygging. Det Norske Veritas (2007) 